\title{
Etnografi Daya Magis Keris Pusaka
}

\author{
Stefanus Rudyanto \\ Dosen Sastra Inggris Fakultas Bahasa dan Sastra Universitas Widya Kartika Surabaya \\ shervyrudianto@yahoo.com
}

\begin{abstract}
Keris pusaka or heirloom keris is a heritage of culture from Indonesia. Speaking about keris pusaka, there are some perspectives, they are, philosophy, art, and magical power inside of it. This research is using ethnography methodology to comprehend the magical power in keris pusaka. The steps of methodology are similar to James P. Spradley's that applied as grand theory in order to elaborate keris' magical power with its abstract ambience. This research is reveals pengagem's in various perspectives toward their keris pusaka and its magical power.
\end{abstract} Keywords: keris pusaka, magical power, ethngraphy

\section{Pendahuluan}

Keberadaan daya magis keris pusaka atau sering diistilahkan sebagai daya isoteri keris pusaka dalam kehidupan masyarakat Indonesia, khususnya masyarakat Jawa mungkin berada pada paparan ada dan tiada. Penempatan daya magis keris pusaka sebagai penelitian ilmiah sungguh merupakan hal yang hampir mustahil dilakukan. Penelitian ini menempatkan sebuah fenomena budaya yang bagi sebagian besar masyarakat dikategorikan dalam ranah mistis dan irasional harus dikaji lewat teori-teori budaya yang ilmiah - nyata dan rasional. Daya magis keris memang sulit untuk dibuktikan secara nyata, namun hal yang bisa dilihat kasat mata dan dapat dibuktikan ialah reaksi masyarakat terhadap keberadaan hal yang sebenarnya sulit dibuktikan ini.

Masyarakat menanggapi daya isoteri keris pusaka dengan berbagai macam reaksi, mulai dari takut, ngeri, penasaran bahkan sampai antipati. Reaksi-reaksi inilah yang nampak nyata. Reaksi takut akan lazim muncul terhadap sesuatu yang

\footnotetext{
${ }^{1}$ Daya kekuatan tidak kasat mata dalam sebilah keris pusaka yang diyakini keberadaannya oleh sebagian anggota masyarakat yang diidentifikasi sebagai pengagem keris pusaka. Dalam pemahaman yang berbeda masyarakat awam juga mengakui keberadaan daya magis ini, terbukti dari reaksi-reaksi masyarakat awam terhadap hal ini yang berupa rasa takut, takjub, heran bahkan ngeri.
} 
sebenarnya tidak diketahui dengan pasti. Rasa takut bisa mengarah pada sikap hatihati namun tak jarang rasa takut membuat orang menjauhi sesuatu.

Daya magis keris telah menjadi bagian dari mitos-mitos sejarah yang berkembang di masyarakat, terutama masyarakat Jawa. Mulai dari cerita-cerita pewayangan, cerita-cerita kethoprak ${ }^{2}$ (babad tanah Jawa), lakon-lakon ludruk ${ }^{3}$ (ceritacerita khas Jawa Timur) sampai pada cerita-cerita silat klasik dan cerpen (cerita pendek) misteri. Tayangan mini seri di televisi serta program-program acara mistis televisi-televisi swasta tak ketinggalan menampilkan tokoh-tokoh yang membawa keris dan memancarkan daya magis.

Sejarah pun mencatat peranan daya magis keris dalam kehidupan tokoh-tokoh di dalamnya. Dalam perang Diponegoro (1825 - 1830), sang pangeran dari Tegal Rejo ini selalu membawa keris pusaka Kyai Carang Mayit ${ }^{4}$ dengan cara diselipkan di pinggangnya (Soeharyono, 2008). Bila keris tersebut menebarkan bau amis, ${ }^{5}$ maka pasukan Diponegoro bakal unggul dalam palagan. Namun bila tercium bau bunga melati dari keris itu, maka akan banyak jatuh korban di pihak pasukan Jawa. Tokohtokoh perjuangan kemerdekaan juga tak ketinggalan menggunakan keris pusaka sebagai senjata andalan dalam melawan penjajah. Jenderal Besar Soedirman membawa (menyengkelit ${ }^{6}$ ) keris pusaka di balik mantelnya. Dalam konteks ini, keris bukanlah senjata untuk menentang Belanda, melainkan sebagai artefak yang diyakini membuat orang yang menyandangnya menjadi lebih berani dan kelihatan lebih berwibawa (Harsrinuksmo, 2004). Bagi masyarakat kota Surabaya, sudah tak asing lagi dengan potret hitam putih Bung Tomo (Sutomo) yang sedang membakar semangat arek-arek Suroboyo dalam pertempuran 10 November. Dalam foto itu jelas terlihat Bung Tomo menyelipkan keris pusaka di bagian pinggangnya. Hal demikianlah yang menyebabkan keberadaan keris beserta kepercayaan akan daya magis di dalamnya melekat erat dan hidup di alam berpikir masyarakat.

\footnotetext{
${ }_{3}^{2}$ Seni pentas drama tradisional yang ceritanya diambil dari babad tanah Jawa

${ }^{3}$ Seni pentas drama khas Jawa Timur/Surabaya dan sekitarnya yang ceritanya diambil dari legenda-legenda lokal maupun cerita kehidupan masa kini.

${ }_{5}^{4}$ Keris pusaka andalan Pangeran Diponegoro yang saat ini berada di Museum kota Leiden - Belanda.

${ }^{5}$ Bau amis dalam hal ini dapat diidentifikasikan sebagai bau darah, dan bukan bau amis seperti pada besi berkarat maupun bau ikan

${ }^{6}$ Menempatkan keris pusaka beserta warangkanya (sarung) dengan cara diselipkan di ikat pinggang atau kain pengikat pinggang yang dalam bahasa Jawa disebut centhing atau kendit.
} 
Sebagai salah satu warisan budaya dunia, keris telah ditetapkan oleh UNESCO sebagai milik bangsa Indonesia pada November 2005 di Paris - Perancis. Sungguh disesalkan bila karena kurangnya pengetahuan tentang keris, terutama daya magisnya lalu masyarakat menjadi anti terhadap keris. Keris pusaka selalu saja dihubungkan dengan hal-hal yang negatif; perdukunan, santet, ilmu hitam, kesesatan, sihir, sirik/musyrik bahkan dengan pesugihan. Stigma-stigma negatif yang melekat pada keris pusaka tak jarang melekat pula pada orang yang memilikinya. Pengagem ${ }^{7}$ keris selalu saja dianggap memiliki kekuatan supranatural dari keris yang ia miliki. Lebih buruknya lagi orang yang memiliki keris dianggap bida'ah ${ }^{8}$ atau sesat sehingga dijauhi.

Berdasarkan pada fenomena tersebut artikel ini merumuskan permasalahan identifikasi serta klasifikasi anggota masyarakat yang memiliki keris pusaka serta merawatnya sebagai pengagem pusaka, cara tiap-tiap pengagem pusaka memaknai daya magis keris pusaka, faktor-faktor yang membuat seseorang tertarik untuk memiliki keris pusaka dan fenomena-fenomena yang diakibatkan oleh daya magis keris pusaka.

\section{Landasan Pemikiran}

Keris merupakan warisan budaya Nusantara dan Melayu (Wibisana, 2010) sehingga keris bukan hanya identik dengan budaya Jawa. Keris lazim pula dipakai oleh orang di Riau, Bugis dan Bali sebagai pelengkap busana mereka (Al-Mudra, 2004), lebih jauh keris juga ditemukan dalam kebudayaan di negara-negara Asia Tenggara lain seperti di Malaysia, Brunai, Philipina Selatan, Singapura dan Thailand (Wooley, 1998).

Keris digunakan untuk mempertahankan diri (misalnya sewaktu bersilat) dan sebagai alat kebesaran diraja. Senjata ini juga merupakan lambang kedaulatan orang Melayu. Keris yang paling masyhur ialah keris Taming Sari yang merupakan senjata Hang Tuah, seorang pahlawan Melayu yang terkenal. UNESCO, sebuah badan

\footnotetext{
${ }_{8}^{7}$ Istilah bahasa Jawa yang digunakan oleh peneliti untuk mendeskripsikan subyek penelitian

8 Tindakan yang dinilai menduakan Tuhan oleh masyarakat, misalnya ritual-ritual sihir, santet, tenung dan lainlain.
} 
Perserikatan Bangsa-Bangsa yang menangani kebudayaan, dalam sidangnya di Paris, 25 November 2005 telah menetapkan keris sebagai warisan budaya dunia yang berasal dari Indonesia. Hal ini memberi predikat sangat istimewa bagi keris Indonesia (keris Jawa dan Bali). Dana internasional pun mengalir masuk untuk kepentingan pelestarian keris. Bangsa Indonesia memiliki tanggung jawab untuk melestarikan keris. Apabila di kemudian hari hasil pengawasan UNESCO menunjukkan bahwa bangsa kita tidak mampu melestarikan artefak budaya ini, bukan tak mungkin bahwa klaim Indonesia akan keris bisa dibatalkan. Negara-negara lain bisa saja memenangkan klaim tersebut.

\section{Sejarah Keris}

Banyak pendapat dan teori mengenai sejarah keris. Teori pertama seperti yang dikemukakan G.B. Gardner dalam bukunya "Keris and Other Malay Weapons" (1936). Gardner menganggap keris sebagai perkembangan lanjut dari jenis senjata tikam zaman prasejarah yang terbuat dari tulang ikan pari. Mengingat bahwa keris kuno zaman purba memang berwujud sederhana menyerupai duri ikan pari (ekor pari) yang lazim disebut keris Bethok. Namun pendapat ini belum sepenuhnya bisa diterima mengingat perkembangan keris beserta pembuatannya berkembang di kawasan yang jauh dari kawasan pesisir sehingga relasi dengan ikan pari sedikit diragukan (Harsrinuksmo, 2004).

Pendapat berikutnya berasal dari Griffith Wilkens, yakni keris merupakan penyederhanaan dari senjata tombak dan baru muncul pada sekitar abad XIV - XV. Tombak lebih sulit dibawa sehingga mata tombak dilepas dan diberi alat pegang yang lebih pendek (handle) supaya mudah dibawa-bawa (Harsrinuksmo, 2004).

Terlepas dari banyaknya pandangan dan teori tentang asal usul keris, penelitian arkeologi menunjukkan bahwa keris telah dikenal oleh orang Jawa sejak abad 5 Masehi. Hal ini dibuktikan dari adanya relief-relief pada candi dan prasasti-prasasti yang ditemukan dan diperkirakan berasal dari abad tersebut. Dalam relief candi Borobudur, tepat di bawah bagian Tenggara, tergambar beberapa prajurit membawa senjata tajam yang meyerupai keris (Maisey, 1998). Hal ini menunjukkan bahwa keris Jawa telah ada sejak masa dimana candi-candi tersebut didirikan. Keris yang berasal dari Kepulauan Jawa dan keris purba telah digunakan antara abad ke-9 dan abad ke- 
14. Senjata ini terbagi menjadi tiga bagian, yaitu bilahan, deder (pegangan) ${ }^{9}$ dan warangka (sarung) ${ }^{10}$. Keris sering dikaitkan dengan kuasa mistik oleh orang Jawa pada zaman dahulu.

Seiring berpindahnya kekuasaan kerajaan ke Jawa Timur, tradisi pembuatan keris mengalami perkembangan yang signifikan. Pada zaman kerajaan-kerajaan seperti Kahuripan, Jenggala, Daha dan Singosari (abad X - XIII), keris-keris yang dihasilkan jauh lebih berkualitas daripada masa Mataram kuno. Keris yang dibuat pada zaman Jenggala terkenal dengan kualitas besinya yang bagus dan penempaan pamornya yang prima (Garret dan Solyom, 1978). Saat ini keris tangguh Jenggala - Singosari menjadi buruan para kolektor karena nilai artistiknya yang sangat tinggi. Ketika kerajaan terbesar muncul, yaitu Majapahit, kebudayaan keris pun tersebar ke seluruh wilayah Nusantara dan Asia Tenggara. Pada masa inilah diduga kebudayaan keris tersebar luas hingga ke kawasan yang sekarang ini disebut Negri Jiran, seperti Malaysia, Brunei, Thailand, Philipina dan Kamboja (Ibid, 1978).

Pada tahap berikutnya pembuatan keris mengalami masa keemasan yaitu pada masa pecahnya Mataram menjadi Surakarta dan Yogyakarta. Pada masa ini terjadi eksplorasi-eksplorasi baru, beragam dapur dan pamor serta pernak pernik keris menjadi sangat dominan. Di samping bentuknya yang lebih besar dari keris-keris masa sebelumnya, pemilihan kualitas bahan juga semakin selektif baik bahan pamor maupun bahan untuk bilahannya (Danujaya, 2000). Sekalipun pada zaman ini keris mengalami puncak prestasinya, namun ada hal yang mulai hilang yaitu peranan keris sebagai "piandel" ${ }^{11}$ sebagai senjata baik lahiriah maupun bathiniah. Pada masa ini keris lebih diperuntukkan sebagai alat pelengkap seremonial, lambang jabatan maupun status sosial. Di kalangan masyarakat Jawa Tengah pada umumnya untuk suatu perhelatan tertentu, misalnya pada upacara perkawinan, para kaum prianya harus mengenakan busana Jawi jangkep (busana Jawa lengkap). Kewajiban itu harus ditaati terutama oleh mempelai pria, yaitu harus menggunakan/memakai busana pengantin gaya Jawa yaitu berkain batik, baju pengantin, tutup kepala (kuluk) dan juga sebilah

\footnotetext{
${ }^{9}$ Kayu, tulang hewan, tanduk atau gading yang berukir yang berfungsi sebagai pegangan sebilah keris

${ }^{10}$ Sarung tempat keris yang terbuat dari kayu

${ }^{11}$ Piandel adalah sebuah manifestasi keyakinan dan kepercayaan dalam wujud benda pusaka yang mengemuka secara fenomenal, penuh daya pukat serta sarat akan lambang yang harus didalami dan dimengerti dengan baik dan benar (Mbah Man, 2013)
} 
keris diselipkan di pinggang. Mengapa harus keris? Karena keris itu oleh kalangan masyarakat di Jawa dilambangkan sebagai simbol kejantanan. Terkadang apabila karena suatu sebab pengantin prianya berhalangan hadir dalam upacara temu pengantin, maka ia diwakili sebilah keris.

\section{Keris Dalam Dunia Pewayangan}

Cerita-cerita dalam pewayangan masih merupakan wacana penting dalam kehidupan masyarakat. Di samping itu kebijakan pemerintah untuk mengembangkan kearifan-kearifan lokal lewat pelestarian budaya-budaya lokal turut membuat wacana tentang pewayangan masih dapat ditemui dalam keseharian masyarakat. Dalam ceritacerita pewayangan keris seringkali ditampilkan sebagai senjata ampuh dengan daya magisnya. Dalam lakon Gatotkaca gugur ${ }^{12}$ dikenal keris pusaka Kuntawijayandanu yang sanggup membunuh tokoh sakti seperti Gatotkaca ${ }^{13}$. Keris tersebut dikisahkan dimiliki oleh Adipati Karna ${ }^{14}$. Dalam perang Bharatayuda ${ }^{15}$, sang Adipati melemparkan senjata pamungkasnya ke arah Gatotkaca. Keris itu melayang sendiri dan segera menghujam ke perut Gatotkaca. Dalam pewayangan seringkali digambarkan para Dewa memakai keris. Hal ini menunjukkan betapa keris erat hubungannya dengan nilai spiritual dan daya-daya supranatural (magis).

\section{Keberadaan Keris Saat Ini}

Keris telah mengalami pergeseran makna dan fungsi dari waktu ke waktu. Beberapa temuan melalui kajian pustaka ini menjadi bahan acuan dalam penelitian ini. Pertama ialah berpindahnya sentra penghasil keris-keris pusaka. Kalau sebelumnya dikatakan bahwa Jawa Tengah merupakan pusat perkerisan dengan Mpu-Mpu yang terkenal, saat ini telah berubah. Sentra kerajinan pembuatan keris-keris pusaka berada di Jawa Timur, tepatnya di Madura. Dalam buku Ensiklopedi Keris (1977) pujangga keris Bambang Harsrinuksmo menyebut desa Aeng Tong Tong, kecamatan Saronggi Kabupaten Sumenep sebagai sentra paling produktif menghasilkan keris-keris pusaka yang berkualitas.

\footnotetext{
${ }^{12}$ Sebuah cerita pewayangan yang mengisahkan gugurnya Gatotkaca ditangan Adipati Karna atas perintah siasat Prabu Kresna.

${ }^{3}$ Putra dari Bima yang merupakan panglima perang dari pihak Pandawa.

${ }_{15}^{14}$ Raja Awangga yang menjadi panglima perang andalan pihak Kurawa.

15 Perang besar antara Pandawa dan Kurawa yang melambangkan pertempuran antara kebaikan melawan kejahatan.
} 
Hal kedua yang menjadi temuan ialah bahwa penggunaan keris yang telah berubah. Kalau dulu keris berfungsi sebagai senjata lalu bergeser menjadi sekedar pelengkap busana atau simbol status sosial, saat ini keris lebih bersifat eksklusif yaitu sebagai barang koleksi. Nilai-nilai estetika dan spiritual keris lebih dominan mendorong orang untuk memiliki keris.

Saya juga melihat keris dari seninya. Tapi bagaimanapun juga keris tak bisa dilepaskan dari unsur mistiknya.

(Hengki Joyo Purnomo, Majalah Keris vol.04/2007)

Dalam hal ini keris-keris lama (kuno) dihargai jauh diatas keris-keris baru atau yang sering disebut tangguh Kamardhikan, yang artinya keris-keris yang dibuat pada era kemerdekaan RI. Keris-keris pusaka yang berusia ratusan tahun selalu saja dihubungkan dengan fenomena-fenomena mistis. Keadaan ini dapat saja menunjukkan bahwa yang bernilai tinggi bukan sekedar bilahan keris saja namun lebih dari itu adalah tuah atau pengaruh daya magis keris-keris tersebut.

Hubungan keris dengan sarungnya secara khusus oleh masyarakat Jawa diartikan secara filosofi sebagai hubungan akrab, menyatu untuk mencapai keharmonisan hidup di dunia. Maka lahirlah filosofi "manunggaling kawula lan Gusti", bersatunya abdi dengan rajanya, bersatunya insan kamil dengan Penciptanya, bersatunya rakyat dengan pemimpinnya, sehingga kehidupan selalu aman damai, tentram, bahagia, sehat sejahtera. Makna yang dalam dari tosan aji sebagai karya seni budaya nasional yang mengandung pelbagai aspek dalam kehidupan masyarakat Indonesia khususnya masyarakat Jawa kini terancam perkembangannya karena artefak budaya ini cenderung kurang diminati aspek legenda dan magisnya.

\section{Daya Magis Keris}

Sedikit sekali informasi faktual yang diperoleh lewat karya-karya mengenai keris pusaka. Dalam berbagai literatur yang ada daya magis keris hanya lewat begitu saja. Dalam karya-karya literatur yang ada tidak banyak ditemukan pernyataanpernyataan yang jelas mengenai keberadaan daya magis keris pusaka. Para penulis hanya berkutat pada sejarah dan cerita-cerita mistis saja tanpa mengungkap lebih dalam hal-hal yang justru bersifat esensial mengenai daya magis keris pusaka. Contoh hal yang esensial misalnya bagaimanakah sebilah keris pusaka mampu mempengaruhi sikap dan tindakan pengagemnya atau pengaruh-pengaruh apa saja yang dapat 
ditimbulkan oleh daya magis sebilah keris pusaka.

Keris pusaka atau tombak pusaka yang merupakan pusaka unggulan itu keampuhannya bukan saja karena dibuat dari unsur besi baja, besi, nikel, tetapi juga dicampur dengan unsur batu meteorid yang jatuh dari angkasa sehingga kokoh kuat. Cara pembuatannya juga disertai dengan iringan doa kepada Sang Maha Pencipta Alam (Tuhan) dengan suatu upaya spiritual oleh Sang Mpu, sehingga kekuatan spiritual Sang Maha Pencipta Alam itu pun dipercaya terinduksi ke dalam bilah keris pusaka tersebut. Keris pusaka itu dipercaya mengandung tuah yang dapat mempengaruhi baik si pengagem pusaka itu sendiri maupun orang-orang disekitarnya. Sebagai contoh, seringkali ada dugaan bahwa usaha dagang seorang pengagem keris pusaka berhasil karena pengaruh daya magis keris pusakanya membuat atau mempengaruhi orang-orang yang berhubungan dengan usahanya.

Keris yang dipakai untuk kelengkapan busana pengantin pria khas Jawa sangat menarik hati. Keris itu dihiasi dengan untaian bunga mawar dan melati yang dikalungkan pada hulu batang keris. Ternyata itu bukan hanya sekedar hiasan, melainkan mengandung makna untuk mengingatkan orang agar jangan memiliki watak beringas, emosional, pemarah, adigang-adigung-adiguna, sewenang-wenang dan mau menangnya sendiri seperti watak Arya Penangsang. Kaitannya dengan Arya Penangsang ialah saat ia berperang melawan Danang Sutawijaya ${ }^{16}$, karena Penangsang pemarah, emosional, tidak bisa menahan diri, perutnya tertusuk tombak Kyai Plered yang dihujamkan oleh Sutawijaya. Usus keluar dari perutnya yang robek. Dalam keadaan ingin balas dendam dengan penuh kemarahan Penangsang yang sudah kesakitan itu mengalungkan ususnya ke hulu keris di pinggangnya. Ia terus menyerang musuhnya. Pada suatu saat Penangsang akan menusuk lawannya dengan keris Kyai Setan Kober di bagian pinggang, begitu keris dihunus, ususnya terputus oleh mata keris pusakanya. Arya Penangsang ${ }^{17}$ mati dalam perang dahsyat yang menelan banyak korban.

Tosan aji atau senjata pusaka seperti tombak, keris dan lain-lain itu bisa

\footnotetext{
16 Putra dari Ki Ageng Pamanahan yang berhasil membunuh Arya Penangsang yang kemudian menjadi raja Mataram dengan gelar Panembahan Senopati.

Adipati Jipang Panolan yang memberontak terhadap kekuasaan Mataram di bawah Sultan Hadiwijaya.
} 
menimbulkan rasa keberanian yang luar biasa kepada pemilik atau pembawanya. Orang menyebut itu sebagai piandel, penambah kepercayaan diri.

\section{Metode Penelitian}

Dalam penelitian yang mengambil topik Daya Magis Keris Pusaka sebagai sebuah kajian etnografi ini diperlukan adanya batasan-batasan ruang lingkup penelitian. Hal ini diperlukan agar fokus utama penelitian dapat dikupas dengan lebih seksama. Dalam penelitian ini terdapat 3 ruang lingkup pembahasan, yaitu :

1. Lokasi penelitian

2. Aspek daya magis keris pusaka (isoteri)

3. Anggota masyarakat yang menjadi subyek

Pertama, penelitian ini akan dilakukan di Surabaya. Terdapat beberapa alasan yang mendasari dipilihnya kota terbesar ke-2 di Indonesia ini sebagai lokasi penelitian:

a. Surabaya adalah kota besar dengan populasi penduduk yang cukup besar; 3,110,187jiwa (http://www.surabaya.go.id/profilkota/index.php?id=22)

b. Terdapat komunitas-komunitas kolektor keris pusaka di kota Surabaya yang cukup signifikan di dunia perkerisan Nusantara, misalnya komunitas Condro Aji, kelompok Adopsi Keris, Warung kopi Ganja Wulung, Pembelajaran Pusaka Nusantara, Keris Jowo, Lingkar Kajian Keris, Grup Keris Holic, Kandang Wesi Aji.

c. Surabaya memiliki sentra-sentra perdagangan keris-keris pusaka, seperti bursa keris di Dupak Grosir, Pasar Turi, Galeri keris Tosan Aji di Royal Plaza

d. Surabaya dekat dengan sentra pengrajin / produsen keris pusaka (desa Aeng Tong Tong, kecamatan Saronggi, kabupaten Sumenep, Madura)

Dengan keempat alasan tersebut maka Surabaya kiranya menjadi lokasi yang paling tepat untuk diadakannya penelitian ini.

Kedua, penelitian ini akan dibatasi pada pembahasan seputar daya magis keris pusaka (isoterik) yang berkaitan langsung dengan kehidupan nyata sehari-hari para pengagem keris pusaka. Meskipun akan dibahas pula sisi-sisi fisik dari keris pusaka, seperti dapur (bentuk), pamor (corak) dan nilai-nilai estetika keris, namun kesemuanya akan bermuara pada efek yang ditimbulkan dalam kaitan dengan daya magis keris pusaka tersebut. 
Ketiga, mengenai populasi yang akan menjadi informan adalah anggota kelompok pengagem keris pusaka. Dalam penelitian awal telah dikategorikan beberapa kelompok pengagem keris berdasarkan pemaknaan terhadap keris itu sendiri.

Penelitian ini menggunakan metode etnografi, maka wilayah tematik dalam kajian ini meliputi 3 sumber. Pertama, dari tanggapan atau persepsi para pengagem keris pusaka mengenai daya magis keris pusaka. Kedua, dari segala bentuk aktifitas yang dilakukan oleh pengagem keris pusaka, seperti misalnya ritual jamasan keris pusaka, pemberian sesaji (suguh) dan ritual-ritual lain. Ketiga, dari berbagai artefak yang berupa koleksi keris pusaka beserta ragam pernak-perniknya yang kesemuanya memberikan makna yang spesifik.

Artikel ini menggunakan pendekatan kuatitatif. Hal ini didasarkan pada tema daya magis yang berupa kumpulan fenomena-fenomena. Artinya, daya magis keris pusaka sebagai sebuah teks budaya mengandung serangkaian kontradiksi-kontradiksi, yakni perbedaan pemahaman masing-masing pengagem keris pusaka terhadap daya magis keris pusaka. Dengan penekanan pada penggunaan metode yang bervariasi sebagai upaya memperoleh pemahaman yang dalam tentang fenomena-fenomena "non ilmiah" sehingga nantinya didapati hasil penelitian yang "ilmiah".

\section{Hasil dan Pembahasan}

\section{Identifikasi Pengagem Keris Pusaka}

Penggunaan istilah pengagem keris pusaka berkaitan erat dengan topik utama artikel ini yaitu daya magis keris pusaka. Adapun alasan-alasan yang mendasari pemilihan istilah tersebut diatas adalah sebagai berikut:

1. Istilah pengagem keris pusaka memiliki makna konotatif ${ }^{18}$ yang menjelaskan perbedaan ciri spesifik antara subyek aktif dalam penelitian ini dan masyarakat yang awam terhadap penelitian, yaitu daya magis keris pusaka.

2. Istilah pengagem berasal dari bahasa Jawa yang memiliki keterkaitan erat dengan penelitian, yaitu keris pusaka yang dalam hal ini yang dimaksud adalah keris pusaka

\footnotetext{
${ }^{18}$ Menurut kamus besar bahasa Indonesia makna konotatif ialah makna tambahan, kesan dan nilai rasa yang dinyatakan secara langsung. Konotasi adalah perubahan nilai arti kata yang disebabkan oleh si pendengar yang memakai perasaannya untuk mengartikan kata itu
} 
dari Jawa.

3. Peneliti belum menemukan istilah dalam bahasa Indonesia yang secara komprehensif dan menyeluruh mampu mempresentasikan gagasan tentang seseorang yang tidak hanya memiliki keris pusaka namun juga memiliki pemahaman spesifik mengenai simbol-simbol yang termanifestasi dalam wujud artefak budaya yang berupa keris pusaka yang ia miliki.

Sebelum mendeskripsikan lebih jauh mengenai para pengagem keris pusaka perlu kiranya diberikan deskripsi mengenai penggunaan istilah ini. Pengagem keris pusaka merupakan sebuah frasa (kelompok kata yang memiliki kesatuan arti) yang terdiri dari 3 (tiga) kata yang terangkai menjadi satu kesatuan dan memiliki makna tersendiri. Frasa pengagem keris pusaka ini dapat dijabarkan lewat paparan pemahaman tiap-tiap kata pembentuknya.

Kata pengagem dalam istilah bahasa Jawa berasal dari kata dasar Agem yang merupakan jenis kata kerja yang dapat diterjemahkan ke dalam bahasa Indonesia secara leksikal dengan kata memegang. Kata lain yang masih berkaitan dengan kata ini ialah kata ageman yang secara denotatif bermakna sesuatu yang dipegang. Berdasarkan makna dari kedua istilah tersebut diatas maka istilah atau kata pengagem secara leksikal ataupun harafiah berarti seseorang yang memegang sesuatu.

Makna tersebut diatas tentu saja terlalu umum untuk dapat mendeskripsikan makna yang sebagaimana dimaksud dalam identifikasi terhadap subyek aktif penelitian ini secara lengkap dan menyeluruh.

Istilah pengagem mampu memberikan tambahan makna yaitu berupa kesan dan nilai rasa yang secara langsung dinyatakan. Tambahan makna yang dimaksud disini ialah bahwa subyek aktif dalam penelitian ini bukan hanya diidentifikasi sebagai seseorang yang memegang sesuatu melainkan lebih kepada sebuah pemahaman dimana orang tersebut memiliki serta memahami simbol-simbol yang termanifestasikan dalam sesuatu yang ia miliki, dalam hal ini keris pusaka. Kesan budaya Jawa sangat dominan dalam penggunaan istilah pengagem ini. Hal ini terkait erat bahwa penelitian yaitu daya magis keris pusaka yang banyak bernuansa kebudayaan Jawa. Sekalipun seperti yang dibahasa terdahulu bahwa keris pada dasarnya tidak dapat serta merta dikategorikan atau bahkan disempitkan maknanya 
sebagai artefak kebudayaan Jawa saja. Nilai rasa yang terkandung dalam kata pengagem sendiri sangat berpengaruh terhadap makna yang ditangkap oleh pendengar. Penggunaan istilah pengagem memberikan sebuah nilai rasa kehormatan dalam pemaknaannya. Ketika seseorang dikatakan sebagai seorang pengagem keris pusaka, pengagem seni budaya, terasa sekali nilai rasa kehormatan didalam penggunaan istilah-istilah tersebut.

Kata pengagem menyatakan makna yang kiranya jauh lebih dalam dari hanya sekedar memegang ataupun memiliki sesuatau. Makna istilah pengagem secara menyeluruh dapat dijelaskan sebagai berikut:

1. Memiliki

Seseorang yang secara sah menguasai hak kepemilikan atas sesuatu baik berupa barang, ide dan gagasan maupun perilaku-perilaku tertentu.

2. Memahami

Seseorang yang memiliki rangkaian makna yang dipahami lewat berbagai cara seperti melalui belajar kepada orang lain, memperkaya wawasan lewat bacaan-bacaan (literatur) maupun dari pengalaman-pengalaman nyata yang ia dapatkan.

3. Keterikatan secara budaya (Cultural Attachment)

Seseorang yang latar belakang budayanya termanifestasi secara spesifik - secara utuh dan menyeluruh dalam wujud sebuah artefak budaya yang ia miliki. Artefak tersebut bisa saja merupakan perwujudan simbolisasi gaya hidup, pola pikir serta lebih dalam gerak spiritualitas dari orang tersebut yang kesemuanya bersumber dari akar budaya dimana orang tersebut berada serta budaya dimana ia lahir dan tumbuh dewasa.

4. Keterikatan secara mental emosional (Emotional Attachment)

Seseorang yang memiliki pemahaman yang mungkin saja diluar dari lingkup rasionalitas terhadap sesuatu yang ia miliki. Secara mental emosional ia memiliki pemahaman terhadap sesuatu yang dimilikinya yang sangat khusus. Hal ini berarti pemahaman orang tersebut mungkin berbeda dengan apa yang dipahami orang lain, keterikatan emotional ini berasal dari pengalaman-pengalaman yang diperoleh secara pribadi oleh orang yang bersangkutan sehingga seringkali sulit untuk dijelaskan secara logis - empiris kepada orang lain.

5. Keterikatan secara spiritual (Spiritual Attachment) 
Seseorang yang memiliki pengalaman tentang sesuatu yang ia miliki yang berupa sebuah keyakinan atau kepercayaan. Sebagai contoh, ketika seseorang terikat secara spiritual terhadap sesuatu, selalu didapati adanya unsur kepercayaan/keyakinan terhadap sesuatu tersebut yang erat kaitannya dengan dinamika spiritual orang tersebut.

\section{Cara pengagem memaknai daya magis keris pusaka}

Dalam penelitian melalui pengamatan langsung peneliti menemukan bahwa ritual-ritual yang dilakukan terlepas dari keharusannya dalam berhubungan dengan daya magis keris pusaka. Peneliti mengamati bahwa ritual-ritual tersebut dilaksanakan dengan atau tanpa meyakini keberadaan daya magis keris pusaka. Pelaksanaan ritual kerap kali lebih kepada upaya melestarikan budaya, menjalankan rutinitas ataupun melaksanakan pesan orang tua yang dibayangi oleh ketakutan apabila tidak melaksanakannya.

Lewat pengamatan langsung dapat disimpulkan sisi pragmatis dari pola pemikiran para piyayi Jawa ini. Mereka beranggapan bahwa ritual yang dijalankan merupakan sebuah bentuk penghormatan kepada para leluhur terlepas dari keyakinan mereka sendiri akan keberadaan daya magis keris pusaka. Ritual yang dijalankan juga tidak memberatkan serta sederhana. Mereka sebagian besar memiliki pemahaman bahwa apabila keris pusaka peninggalan orang tua (leluhur) tidak disertai dengan pelaksanaan ritual maka keris pusaka tersebut akan mendatangkan hal-hal yang tidak diinginkan.

Para piyayi Jawa masih meyakini bahwa keris pusaka tersebut malati $^{19}$, artinya apabila tidak dirawat dengan baik atau tidak diperlakukan dengan hormat bisa mendatangkan kutukan. Dari kesaksian seorang informan yang memiliki keris pusaka warisan orang tua, peneliti mendeskripsikan hal tersebut diatas dalam sebuah rangkaian peristiwa. Ibu Winarsih, seorang piyayi Jawa yang tinggal di wilayah Sidoarjo mengisahkan peristiwa yang berhubungan dengan pemahaman bahwa keris pusaka dapat mendatangkan kutukan bila tidak diperlakukan sebagaimana mestinya. Keris milik keluarga Ibu Winarsih, menurut yang bersangkutan telah dipesankan oleh

\footnotetext{
${ }^{19}$ Keyakinan bahwa sebuah barang yang diperlakukan tidak dengan hormat atau tidak sesuai dengan adat dapat mendatangkan kutukan atau bencana
} 
orang tuanya agar tidak diletakkan/ditempatkan di ruang tamu atau ruang dimana orang luar (bukan keluarga) dapat melihatnya. Meminjam istilah yang dipakai Ibu Winarsih; keris pusaka tersebut tidak suka dipamerkan. Suatu ketika keris tersebut secara tidak sengaja, tanpa disadari ataupun lupa ditempatkan menempel pada dinding ruang tamu. Setelah beberapa waktu putra Ibu Winarsih mengalami sakit. Ketika dibawa berobat ke dokter diketahui bahwa putra Ibu Winarsih tidak mengalami gangguan penyakit apapun. Kemudian Ibu Winarsih menyadari kesalahannya dan segera memindahkan keris tersebut ke ruang lain. Begitu hal tersebut dilakukan, maka kesehatan putra Ibu Winarsih berangsur membaik. Demikian kesaksian dari Ibu Winarsih ini dapat dijadikan informasi serta dapat disimpulkan bahwa piyayi Jawa masih meyakini konsep malati dari daya magis keris pusaka.

Selain meneliti makna daya magis keris pusaka bagi para piyayi Jawa, peneliti selanjutnya juga akan menggali informasi mengenai ritual-ritual yang berhubungan dengan keyakinan akan adanya daya magis keris pusaka. Ritual- ritual tersebut merupakan bentuk budaya perilaku (Cultural Behavior) seperti yang dinyatakan oleh Koentjaraningrat. Ritual-ritual tersebut merupakan manifestasi atau perwujudan pola pikir termasuk keyakinan serta pemahaman yang dimiliki oleh para piyayi Jawa akan daya magis keris pusaka.

Dalam pengamatan dengan metode partisipasi langsung peneliti menemukan bahwa ritual-ritual yang dilakukan seringkali terlepas dari keharusannya dalam berhubungan langsung dengan daya magis keris pusaka. Ritual-ritual dilakukan dengan atau tanpa meyakini keberadaan daya magis keris pusaka. Diantara ritual-ritual yang paling umum dilakukan naik secara rutin maupun tidak terdapat beberapa ritual yang dapat diinventarisasi lewat pengamatan langsung. Berikut ini peneliti mendeskripsikan pelaksanaan ritual tersebut beserta makna yang terkandung di dalamnya:

a. Ritual menjamasi pusaka

Ritual menjamasi pusaka atau yang sering disebut ritual jamasan pusaka dilakukan paling sedikit 1 kali dalam setahun, biasanya pada bulan Sura menurut penanggalan Jawa. Pada ritual ini keris-keris pusaka dibersihkan atau disucikan dengan cara dimandikan/dicuci dengan menggunakan air kembang 7 rupa (setaman) 
serta melalui ritual-ritual pembacaan doa oleh seorang pinisepuh, yakni seorang yang ahli dalam menjamas keris pusaka. Berdasarkan keterangan dari Bapak Budi lewat serangkaain wawancara, ritual jamasan ini pada dasarnya bertujuan untuk membersihkan/menyingkirkan daya-daya magis susulan yang mungkin saja terinduksi ke dalam sebuah keris pusaka. Ketika daya-daya magis yang tidak diinginkan tersebut sudah hilang, maka yang ada pada keris pusaka tersebut diyakini oleh si pengagem, ialah daya magis asli yang diinduksikan oleh Mpu si pembuat keris pusaka tersebut.

b. Ritual mengutuki keris pusaka

Ritual ini dapat dilakukan kapan saja dan sangat sederhana. Mengutuki keris ialah prosesi ritual pribadi seorang pengagem keris pusaka.

Ritual ini diyakini mampu menambah keampuhan keris pusaka. Pengaruh magisspiritual yang terpancar dari sebuah keris dapat dirasakan oleh seorang pengagem keris pusaka. Adapun hal-hal yang diyakini diperoleh lewat ritual ini adalah sebagai berikut:

1. Daya magis keris pusaka semakin kuat apabila sering dikutuki apalagi bila dilakukan secara rutin.

2. Seorang pengagem keris pusaka dapat mengerakkan/menggunakan daya magis keris pusaka untuk keperluan-keperluan tertentu, misalnya, untuk persiapan perang, menjaga keamanan rumah, menjaga keselamatan dalam perjalanan dan lain-lain.

3. Daya magis keris pusaka dapat memberi petunjuk atau dalam bahasa Jawa disebut wangsit, lewat petunjuk mimpi maupun penampakan langsung.

c. Ritual memberikan sesajen pada hari-hari tertentu

Ritual pemberian sesajen ini disebut juga ritual sandingan (bahasa Jawa). Dalam ritual ini keris-keris pusaka dipersonifikasikan sebagai perwujudan roh para leluhur atau dewata yang wajib diberikan sesajen. Sesajen ini dapat berupa seperangkat alat dan bahan yang sederhana sampai pada yang lengkap dan rumit. Sesajen tersebut diatas diberikan pada hari-hari tertentu yang menurut tradisi Jawa dikenal sebagai hari-hari baik. Adapun pelaksanaan ritual biasanya dilakukan setelah matahari terbenam (selepas maghrib). Adapun hari-hari yang diyakini sebagai hari baik tersebut ialah sebagai berikut:

- Hari Kamis - malam Jumat Legi 
Hari ini termasuk dalam hitungan sebagai hari Anggoro Kasih karena neptunya (perhitungan Jawa) untuk hari ini ialah berjumlah 11 (Jum"at 8 dan Legi 3, jadi bila dijumlah menjadi 11). Angka sebelas dalam bahasa Jawa disebut sewelas yang dihubungkan dengan kata sak-welas, yang bermakna sebagai memohon belas kasih Tuhan (sak welas asihing Gusti - bahasa Jawa). Menurut keyakinan masyarakat Jawa malam Jum;at Legi ini adalah saat yang paling tepat untuk memohon sesuatu kepada Tuhan Yang Maha Esa. Hal ini disebabkan orang Jawa yakin bahwa doa-doa permohonan banyak dikabulkan oleh Tuhan bila didoakan pada waktu tersebut.

- Hari Kamis - malam Jumat Kliwon

Masyarakat di Jawa khususnya yang masih mempercayai perhitungan hari berdasarkan warisan leluhur sangat percaya bahwa malam Jum"at Kliwon adalah malam yang keramat. Dari hasil wawancara dengan beberapa informan, peneliti mendapat informasi bahwa malam Jumat Kliwon ini dikeramatkan karena pada malam tersebut batas antara alam nyata dan alam astral terbuka.

- Hari Senin - malam Selasa Kliwon

Malam Selasa Kliwon merupakan malam utama dari perhitungan hari Anggoro Kasih. Pada malam ini dipercaya bahwa daya cinta kasih Tuhan tercurahkan kepada umatnya. Masyarakat Jawa meyakini bahwa malam Selasa Kliwon adalah saat yang tepat untuk memohon cinta kasih Tuhan dalam bentuk pertolongan maupun perlindungan Tuhan. Keris-keris pusaka yang diyakini memiliki daya magis yang bersifat welas asih sebaiknya diberikan sesajen pada malam Selasa Kliwon.

- Malam kelahiran sang pengagem keris pusaka

Para pengagem keris pusaka dari kelompok piyayi Jawa biasanya melakukan ritual sandingan bagi keris-keris andalan mereka pada malam kelahirannya (weton). Hal ini dilakukan dengan tujuan agar daya magis keris pusaka menyatu dengan diri/jiwa si pengagem pusaka atau menggunakan istilah Jawa yaitu manunggal roso. Para pengagem keris pusaka meyakini bahwa bila sebuah keris pusaka diberikan sesajen secara rutin pada hari kelahiran seorang pengagem maka daya magis keris pusaka tersebut akan senantiasa menyatu dengan pribadi pengagemnya.

- Malam 1 Suro

Malam 1 Suro merupakan malam yang paling dikeramatkan oleh masyarakat 
Jawa khususnya yang masih menganut paham kejawen. Di kalangan masyarakat Jawa yang sudah beragama Islam, malam 1 Suro disebut dengan malam 1 Muharram. Pada dasarnya malam 1 Suro ialah malam pergantian tahun dan seperti layaknya malam tahun baru, banyak masyarakat yang merayakannya.

d. Memberikan kalung bunga melati

Ritual pemberian rangkaian bunga melati yang dikalungkan pada keris pusaka (melati rinonce - bahasa Jawa) merupakan ritual yang kerap kali dilakukan terutama pada keris-keris pusaka andalan yang oleh pengagemnya diyakini memiliki daya magis yang lebih besar diantara keris-keris pusaka lain yang ia miliki. Memberikan rangkaian melati pada keris pusaka ini memiliki latar belakang sejarah yang cukup menarik untuk disimak. Pemahaman para piyayi Jawa tentang ritual ini tidak lepas dari cerita sejarah Babad Tanah Jawa tentang sepak terjang Adipati Jipang Panolan, Raden Arya Penangsang.

e. Mengolesi keris dengan minyak wangi

Minyak wangi merupakan piranti yang sangat akrab dengan aktifitas-aktifitas supranatural. Dalam pelbagai ritual keagamaan, bau-bauan yang harum merupakan hal yang tidak pernah terlewatkan. Bau harum bisa berasal dari asap dupa, kemenyan maupun hio, bisa pula berasal dari bunga-bunga tertentu, seperti melati, mawar, sedap malam dan kenanga. Namun, ketika membahas soal praktisnya, maka bau harus didapat dari minyak wangi. Dalam beberapa agama, seperti agama Islam misalnya, Nabi Muhammad SAW menyarankan umatnya untuk menggunakan minyak wangi ketika melaksanakan ibadah sholat.

\section{Daya Tarik Keris Pusaka}

Peneliti memerlukan waktu yang cukup lama dan pendekatan yang lebih internsif lewat beberapa kali kesempatan wawancara untuk menggali informasi seputar pemaknaan daya magis keris pusaka oleh para kolektor keris pusaka ini.

Dalam wawancara, peneliti menjumpai kekhawatiran para kolektor keris pusaka akan stigma negatif yang melekat pada keris pusaka beserta pengagemnya. Hal ini dapat tersirat dalam wawancara dengan beberapa kolektor keris pusaka yang berhasil ditemui oleh peneliti.

Seperti telah dijelaskan pada bagian sebelumnya bahwa fokus utama - alasan 
utama para pengagem keris pusaka dalam kelompok ini ialah keindahan dan seni dari bentuk fisik keris pusaka. Namun seiring berjalannya waktu - wawancara yang dilakukan peneliti mengungkap bahwa para kolektor keris Para kolektor keris pusaka merasakan hal-hal yang menurut mereka merupakan rasa yang didapat ketika mereka berada dekat dengan koleksi keris-keris mereka, seperti yang dapat disimak dari petikan wawancara yang akan diberikan di akhir bagian ini.

Rasa-rasa yang diperoleh ketika seorang kolektor keris pusaka dan sekaligus pengagem keris pusaka antara lain:

1. Ketenangan jiwa/bathin

2. Kepuasan diri karena telah melestarikan budaya bangsa

3. Kebanggaan pribadi

4. Harapan akan pertolongan Tuhan melalui perantaraan daya magis keris pusaka

Para kolektor keris pusaka memiliki khazanah kriteria-kriteria yang secara umum dapat dikatakan sama, antara seorang kolektor keris pusaka dan lainnya. Pada wawancara-wawancara awal domain pembicaraan selalu berkaitan dengan wujud fisik keris pusaka. Para kolektor keris sangat jeli dan bahkan dapat dikatakan ahli dalam mengamati dan menilai wujud keris pusaka. Hal-hal yang menjadi perhatian utama para kolektor keris pusaka ketika menilai sebuah keris pusaka antara lain:

1. Dapur $^{20}$ (wajah) berarti wujud atau bentuk keris.

2. Pamor artinya campuran. Sederhananya pamor adalah hiasan pada bilah keris yang nampak lebih terang dari warna logam bilahnya. Hal ini berkat logam campuran yang diikutan pada penempaan saat proses pembuatan keris.

3. Dalam dunia perkerisan dikenal pula istilah pasikutan. Yang dimaksudkan adalah kesan selintas, ketika memandang bentuk keris. Kesan ini tentu saja hanya bisa dirasakan oleh para kolektor keris pusaka.

4. Pertimbangan lain yang tak kalah pentingnya adalah Tangguh. Yang dimaksudkan adalah gaya daerah asal atau gaya jaman pembuatan keris tersebut.

Ketika wawancara telah mencapai tahap kedekatan yang lebih akrab, maka sisi mistis dari pertimbangan para kolektor keris pusaka perlahan-lahan mulai terungkap. Para kolektor keris pusaka ternyata meyakini bahwa keris pusaka memiliki daya magis

\footnotetext{
${ }^{20}$ Bentuk fisik dari bilahan keris pusaka.
} 
atau yang kerap kali disebut daya isoteri keris pusaka. Para kolektor keris pusaka tidak melulu memakai pertimbangan wujud fisik sebagai dasar/alasan untuk mengoleksi sebuag keris pusaka. Daya magis keris pusaka merupakan aspek penting dalam menentukan apakah sebuah keris pusaka layak dikoleksi atau tidak.

Keris-keris pusaka kuno tentu saja menjadi incaran para kolektor keris pusaka. Ada beberapa hal yang membuat keris-keris pusaka kuno tersebut menjadi sangat berharga di mata para kolektor. Di antara alasan-alasan mengapa keris-keris pusaka kuno tersebut menjadi incaran ialah sebagai berikut:

1. Nilai historis keris pusaka

2. Nilai koleksi keris pusaka

3. Daya magis keris pusaka kuno

\section{Fenomena Keris Pusaka}

Berangkat dari konsep wujud budaya yang disampaikan oleh Koentjaraningrat bahwa wujud budaya dapat berupa gagasan atau ide (Cultural Knowledge), wujud perilaku (Cultural Behavior) dan wujud hasil perilaku (Cultural Artefact) (Koentjaraningrat, 2002), maka keberadaan daya magis keris pusaka ini merupakan sebuah manifestasi atau perwujudan dari sebuah budaya. Ide atau gagasan mengenai daya magis keris pusaka ini kiranya tidak dapat dipisahkan dari perwujudan yang lainnya seperti perilaku para pengagem keris pusaka, misalnya melakukan ritual-ritual yang berhubungan dengan keyakinan mereka akan adanya daya magis dalam sebilah keris pusaka.

Beberapa pengagem pusaka melakukan ritual suguh, yakni ritual mempersembahkan sesajen kepada roh leluhur yang berada di dalam keris pusaka berupa kembang melati, kembang tiga rupa (telon), kopi pahit dan kopi manis, teh manis serta dupa atau kemenyan pada malam Jumat Legi yang menurut perhitungan penanggalan Jawa merupakan hari baik atau yang termasuk dalam hitungan hari Anggoro Kasih ${ }^{21}$. Wujud perilaku ini merupakan salah satu wujud budaya perilaku (Cultural Behavior). Wujud fisik atau benda dari keris pusaka itu sendiri tentu saja

\footnotetext{
${ }^{21}$ Hari dalam perhitungan Jawa yang penjumlahan hari dan pasarannya adalah 11 (sebelas). Diyakini masyarakat Jawa bahwa pada hari-hari tersebut sangat baik untuk melakukan doa-doa permohonan kepada Tuhan Yang Maha Esa maupun melakukan ritual-ritual olah bathin.
} 
dapat dipandang sebagai sebuah wujud hasil perilaku budaya (Cultural Artefact). Dalam melakukan kajian identitas budaya suatu masyarakat, ketiga perwujudan budaya tersebut kerap kali dijadikan pengamatan serta kajian yang mendalam oleh para peneliti.

Pada berbagai kasus perilaku seorang pengagem keris pusaka seringkali dikategorikan sebagai perilaku menyimpang atau sebagian kalangan misalnya para agamawan bahkan memberikan pernyataan bahwa perilaku para pengagem keris pusaka tersebut sesat. Keunikan perilaku dan pola pikir seorang pengagem keris pusaka menjadi bahan dasar kajian etnografi tentang daya magis keris pusaka ini.

Kajian mendalam tentang daya magis keris pusaka kiranya tidak akan terlepas dari konsep-konsep tentang simbol-simbol budaya. Ernest Cassirer dalam bukunya Manusia dan Kebudayaan: Sebuah Esai Tentang Manusia, menyatakan konsep tentang manusia sebagai animal symbolicum. Hal penting yang ditemukan dalam konsep ini ialah bahwa manusia dibedakan dari makhluk ciptaan Tuhan lainnya berdasarkan kemampuan manusia dalam menciptakan serta memahami simbol-simbol.

Pemahaman tentang daya magis keris pusaka sarat dengan kemampuan para pengagem keris pusaka untuk berpikir dan memahami simbol-simbol yang berkaitan dengan daya tersebut. Tindakan-tindakan yang dilakukan oleh seorang pengagem keris pusaka juga merupakan tindakan-tindakan simbolis. Seorang pengagem keris pusaka tentu saja melakukan gerakan-gerakan khusus yang mengandung arti khusus pula serta merupakan simbol pemahamannya terhadap daya magis keris pusaka. Sebagai contoh, ketika seorang pengagem keris pusaka hendak menarik keluar sebilah keris pusaka dari sarung (warangka) keris tersebut ia akan terlebih dahulu meletakkan/menempelkan keris beserta warangkanya pada keningnya. Perilaku ini merupakan perilaku simbolis yang mewujudkan sebuah penghormatan terhadap daya magis yang dalam pemahaman seorang pengagem keris pusaka berada dalam keris pusaka yang sedang dipegangnya tersebut.

Keris pusaka sebagai sebuah benda hasil perilaku budaya (Cultural Artefact) merupakan manifestasi dari simbol-simbol budaya yang merupakan cerminan pola tatanan hidup dan pemahaman spritualitas dari masyarakat sebagai sebuah entitas budaya. Bentuk keris (dapur) yang bermacam-macam jenis adalah simbolisasi pesan 
tentang apa yang dapat dihayati sebagai hasil dari penghayatan tentang kehidupan. Sebagai contoh, bentuk keris yang condong ke depan (condong leleh) menggambarkan manusia yang sedang membungkukkan badannya yang dapat diartikan seseorang yang menyembah kepada Tuhan pencipta alam semesta. Bentuk lurus merupakan sebuah tuntunan untuk bertakwa kepada Tuhan serta bentuk berlekuk atau keluk seperti asap dupa yang berkeluk-keluk menuju kearah atas sebagai manifestasi menuju kemanunggalan terhadap sang Maha Kuasa. Ratusan bentuk dapur mencerminkan bermacam-macam harapan, dapur Brojol misalnya, adalah sebuah pengejawantahan keinginan manusia untuk dapat lancar (mbrojol) dalam hal menyelesaikan kesulitan yang dihadapinya.

Menurut seorang pakar perkerisan yang sekaligus pembuat keris pusaka $(\mathrm{Mpu})$ KRT. Subandi Suponingrat pemahaman tentang daya magis keris pusaka digolongkan dalam 5 (lima) pemahaman, yaitu:

1. Daya imajinasi yang tertanam pada keris pusaka yang dapat dideteksi secara elektromagnetis (menggunakan pendulum sebagai alat pendeteksi). Dengan kemampuan-kemampuan tertentu getaran energi akan menyentuh cakra-cakra manusia akan ditangkap atau dirasakan sebagai getaran.

2. Daya yang dipersonifikasikan dalam bentuk gambaran sosok-sosok makhluk halus lewat kekuatan visualisasi alam bawah sadar. Hal ini terjadi karena ingatan dan wawasan pengetahuan yang telah dimiliki oleh seseorang.. Maka ada seni tayuh pusaka seperti telah dikenal sebagai tradisi sampai kini dengan berbagai cara dan ritual yang berbeda-beda.

3. Penginderaan visual-estetis, munculnya suatu rasa takjub oleh hasil ekspresi dari wujud yang tertanam melalui proses intuitif, kreatif dan reka ulang ingatan/penghayatan dalam sentuhan pada karya.

4. Pemahaman semiotik, antara lain simbol (tanda) yang dipahami sebagai maksud yang melahirkan harapan. Seperti lingkaran-lingkaran motif pamor udan-mas sebagai harapan kerejekian, garis lurus bertumpuk sebagai singkir dan metafora pamor rondoru (motif seperti gambar daun palma), blarak sinered, junjung drajat dll, sebagai simbol kemuliaan, derajat dan kemakmuran. (Drs. Budihardjo Wirjodirdjo M.Sn. Tentang semiotika Keris.; Jurnal "SENI", ISI -Yogyakarta). 
5. Pesan filosofis sebagai isoteri yang dapat memberi keyakinan (confidence) pada pemiliknya. Misalnya, keris jangkung (bentuk keris luk 3) sebagai kekuatan yang dapat menumpu terjangkaunya cita-cita.

Pendapat pakar perkerisan tersebut diatas didukung oleh hasil penelitian ini. Makna-makna yang diyakini oleh kelima kelompok pengagem keris pusaka membuktikan bahwa deskripsi daya magis keris pusaka adalah seperti yang tersebut diatas.

Pada saat ini keris pusaka dengan daya magisnya harus menghadapi tantangan jaman. Pendapat antara satu kelompok pengagem keris pusaka dengan yang lain yang berbeda bahkan bertentangan mengindikasikan bahwa keris pusaka telah menjadi obyek penderita dalam hal ini. Keris pusaka yang sebenarnya tidak secara nyata melakukan aktivitas harus mendapat label dari masyarakat atas aktivitas-aktivitas pengagemnya. Ketika makna-makna daya magis keris pusaka dianalisa secara mendalam maka ditemukan bahwa pengagem keris pusakalah yang sebenarnya aktif menciptakan makna daya magis keris pusaka.

\section{Simpulan}

Sebagai hasil penelitian didapati bahwa berbicara mengenai daya magis keris pusaka sebenarnya yang dideskripsikan ialah lebih pada konsep-konsep pemahaman para pengagemnya dan bukan pada konteks magis keris pusaka itu sendiri. Melalui penelitian ini dapat dipahami bahwa daya magis keris pusaka mencakup makna-makna sebagai berikut:

1. Daya magis keris pusaka merupakan konsep yang diwariskan dari para pendahulu (inherent).

2. Daya magis keris pusaka merupakan konsep yang dapat dipelajari secara ilmiah (learnt).

3. Daya magis keris pusaka merupakan konsep yang dapat digunakan untuk menambah nilai jual artefak budaya ini sendiri (Comodification).

Keberadaan konsep-konsep daya magis keris pusaka inilah yang membedakan keris dari artefak budaya yang lain. Masyarakat awam pada umumnya tidak memahami secara benar dan mendalam tentang keris pusaka dan mitos-mitos yang 
menyertainya. Sebagai akibatnya banyak kalangan masyarakat yang antipati terhadap keris pusaka. Ketidaktahuan selalu saja menimbulkan rasa curiga, takut bahkan tidak suka terhadap sesuatu. Pengetahuan tentang keris saat ini bukan lagi menjadi rahasia milik para bangsawan atau pengagem keris pusaka semata. Pengetahuan tentang keris atau yang disebut dengan Krisologi terbuka bagi siapa saja yang ingin mempelajarinya.

\section{Daftar Pustaka}

Al-Mudra, M. 2004. Keris dan Budaya Melayu. Yogyakarta. Balai Kajian dan Pengembanga Budaya Melayu.

Cassier, Ernest. 1990. Manusia dan Kebudayaan: Sebuah Esai Tentang Manusia. Jakarta: Gramedia.

Danujaya, B. 2000. 1000 Tahun Nusantara. Jakarta: Penerbit Buku Kompas.

Gardner, Gerald B. Keris and Other Malay Weapons. Orchid Press; Reprint Edition 2010 ISBN 978-974-8304-29-8 (Originally Printed 1936 Singapore: Progressive Publishing Company)

Harsrinuksmo, Bambang. Ensiklopedia Budaya Nasional.

Koentjoroningrat. 2002. Pengantar Ilmu Antropologi. Jakarta: Rineke Cipta.

Maisey, A.G. 1998. "Origin of The Keris and Its Development to the $14^{\text {th }}$ Century" hlm 8-23. dlm Arrms Cavalcade, Official Journal of the Antique Arms Collectors Society of Australia Co-op Limited. 1:2 April.

Purnomo, Hengki Joyo. 2007. Majalah Keris volume 04/2007.

Soeharyono, B. 2008. Peran Keris Dalam Sejarah. http://kerisologi.multiply.com/journal/item/8 Diakses 21 Juli 2008.

Solyom, Garret and Bronwyn. The World of The Javanese Keris.

Wooley, G.C. 1998. "Keris: Its Origin and Development" dlm Hill etc. The Keris and Other Malay Weapons. Kuala Lumpur: The Malaysian Branch of the Royal Asiatic Society. 